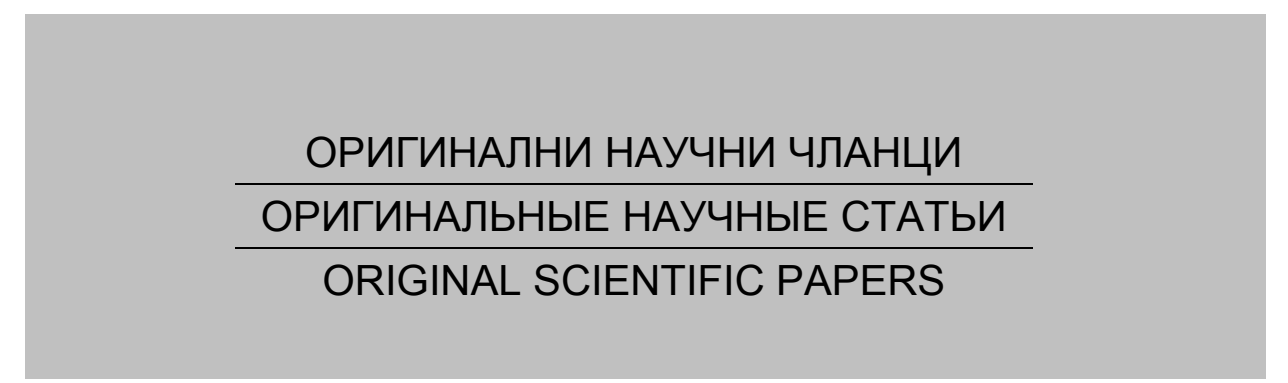

\title{
STRONG ENHANCEMENT OF DOUBLE AUGER DECAY FOLLOWING PLASMON EXCITATION IN C 60
}

Sanja Lj. Korica ${ }^{\mathrm{a}}$, Axel Reinköster ${ }^{\mathrm{b}}$, Uwe Becker $^{\mathrm{c}}$
${ }^{\mathrm{a}}$ University Union - Nikola Tesla, Faculty for Ecology and
Environmental Protection, Belgrade, Republic of Serbia +
Fritz-Haber-Institut, Department of Molecular Physics,
Berlin, Federal Republic of Germany,
e-mail:koricasanja@gmail.com,
ORCID iD: Dhttp://orcid.org/0000-0002-7915-9430
b Fritz-Haber-Institut, Department of Molecular Physics,
Berlin, Federal Republic of Germany
${ }^{c}$ Fritz-Haber-Institut, Department of Molecular Physics,
Berlin, Federal Republic of Germany
DOI: 10.5937/vojtehg66-16269; https://doi.org/10.5937/vojtehg66-16269

FIELD: molecular physics, synchrotron radiation, photoelectron spectroscopy,

fullerenes, dipole resonance, Auger decay, Plasmon, collective oscillation, localized excitation, delocalized relaxation

ARTICLE TYPE: Original Scientific Paper

ARTICLE LANGUAGE: English

Abstract:

One of the important characteristics of the $C_{60}$ molecule is the collective response of its valence electron cloud to the electromagnetic radiation. This collective behavior gives rise to the occurrence of the giant dipole resonance (so called surface plasmon) in the absorption spectrum centered around $20 \mathrm{eV}$, which has also been analyzed theoretically by various authors. Concerning photoelectron emission, plasmonic excitation is characterized by a particular intensity behavior near the threshold. We present here a new series of the K-shell photoelectron spectra with particular emphasis on the qualitative analysis of all ionization with excitation and double ionization processes. Our measurements of the $C_{60}$ plasmon excitation follow the so-called Thomas-Derrah law and are in good agreement with the corresponding behavior of satellite excitations in atoms such as neon.

Key words: molecular physics, photoelectron spectroscopy, plasmon excitation.

ACKNOWLEDGMENT: The authors are indebted to the Deutsche Forschungsgemainschaft (DFG) and to the Bundesministerium für Bildung und Forschung (BMBF) for the financial support. 


\section{Introduction}

Since the discovery of $\mathrm{C}_{60}$ molecule (Kroto et al, 1985, pp.162-163), (Krätschmer et al, 1990, pp.354-358) many studies have been performed to investigate its fundamental properties. These properties are mainly driven by its unique molecular structure like a spherical shell (Electronic Properties of Fullerenes, 1993), (Korica et al, 2005, pp.132031-132035). $\mathrm{C}_{60}$ is known to have a plasmon excitation where 240 valence electrons contribute to a delocalized electron cloud that can oscillate relative to the carbon ion core forming the $\mathrm{C}_{60}$ molecular cage. This oscillation produces a giant resonance in the $\mathrm{C}_{60}$ photoabsorption (Hertel et al, 1992, pp.784787) and electron-energy-loss spectra (Leiro et al, 2003, pp.205-213) at the excitation energy of about $20 \mathrm{eV}$. It has also been observed in the photofragmentation experiments as an enhanced relative fragmentation of $\mathrm{C}_{60}{ }^{+}$ion at the same photon energy (Karvonen et al, 1997, pp.34663472). It has been interpreted by different theoretical models as a dipole collective giant resonance (Amusia \& Connerade, 2000, pp.41-70), (Bertsch et al, 1991, pp.2690-2693), (Ekardt, 1984, pp.1925-1928), due to autoionization, which arises from collecting the strength of the individual one-electron transitions into a single collective excitation.

\section{Experimental set-up}

The measurements were performed at the HASYLAB undulator beam line BW3 in Hamburg using monochromatized synchrotron radiation whose wavelength can be scanned with a resolution set to an appropriate value. The photon beam crosses an effusive beam of $\mathrm{C}_{60}$ molecules, provided by an oven heated to $500{ }^{\circ} \mathrm{C}$. Outgoing electrons are detected in time-of-flight (TOF) electron spectrometers at two different angles with respect to the electric vector of the ionizing radiation (Fig. 1). Appropriate voltages can be applied to the TOF-analysers to keep a constant resolution of the electron spectra for different photon energies. 


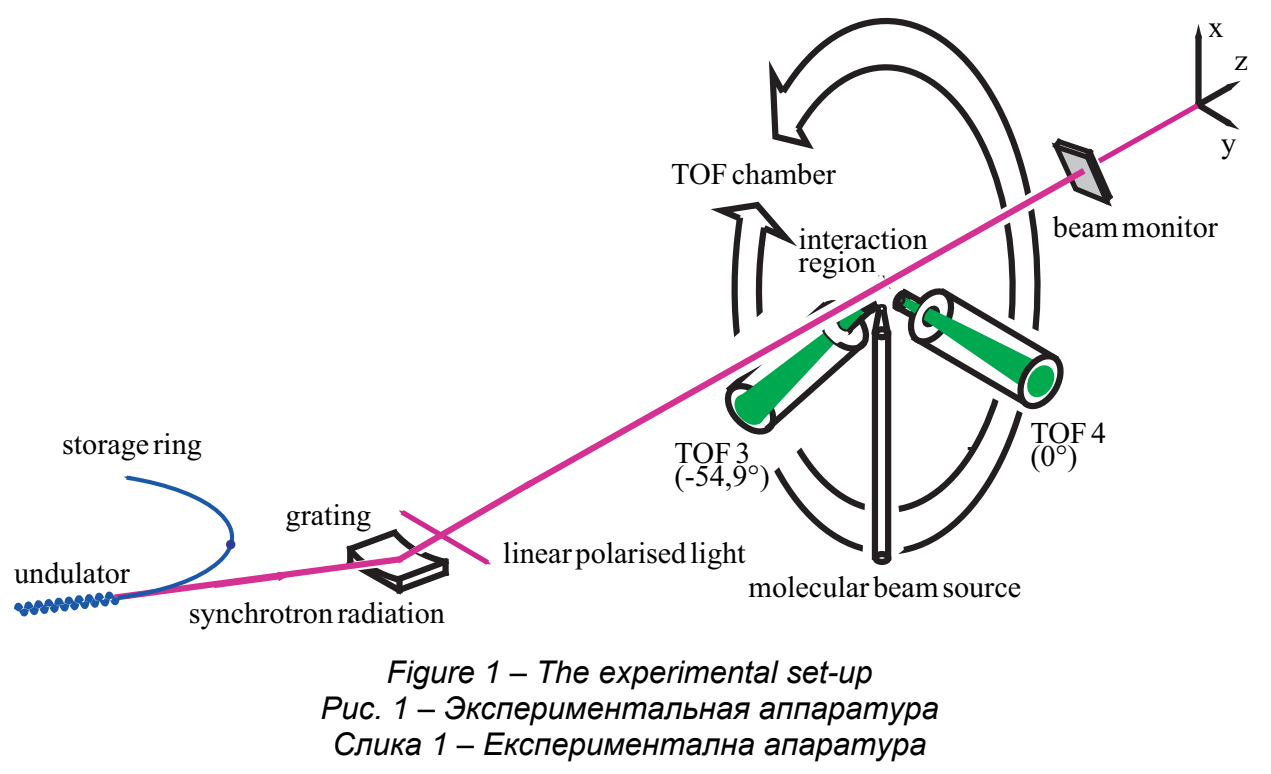

\section{Results and Discussion}

\section{Plasmon excitation in $\mathrm{C}_{60}$ molecule}

Figure 2 shows an example of the K-shell photoelectron spectrum of $\mathrm{C}_{60}$, recorded at $390 \mathrm{eV}$ photon energy, covering the whole range of kinetic energies down to zero kinetic energy. The spectrum is converted to the binding energy and the background has been subtracted.

The spectrum consists, besides the single narrow $\mathrm{C}(1 \mathrm{~s})$ main line (Lichtenberger et al, 1991, pp.203-208), of a variety of satellite lines and higher lying plasmon excitation (Weaver et al, 1991, pp.1741-1744), (Benning et al, 1992, pp.6899-6913), (Terminello et al, 1991, pp.491496). The low binding energy side of the $\mathrm{C} 1 \mathrm{~s}$ (from $1.9 \mathrm{eV}$ to $9.3 \mathrm{eV}$ ) is characterized by different dipole and monopole shake-up satellites, except the one at the $6.0 \mathrm{eV}$ which relates to the $\pi$ plasmon. The energy region between $10 \mathrm{eV}$ and $20 \mathrm{eV}$ does not have discrete dipole transitions for free molecules and collective resonances are the dominating effects here (plasmon like excitations). The broad peak at the high binding energy side is also caused by several plasmon excitations.

Such plasmons are supposed to originate from a collective motion of $\sigma$ - and/or $\pi$-electrons in the electric hull of the $\mathrm{C}_{60}$ molecules following the ionization of a K-shell electron. 


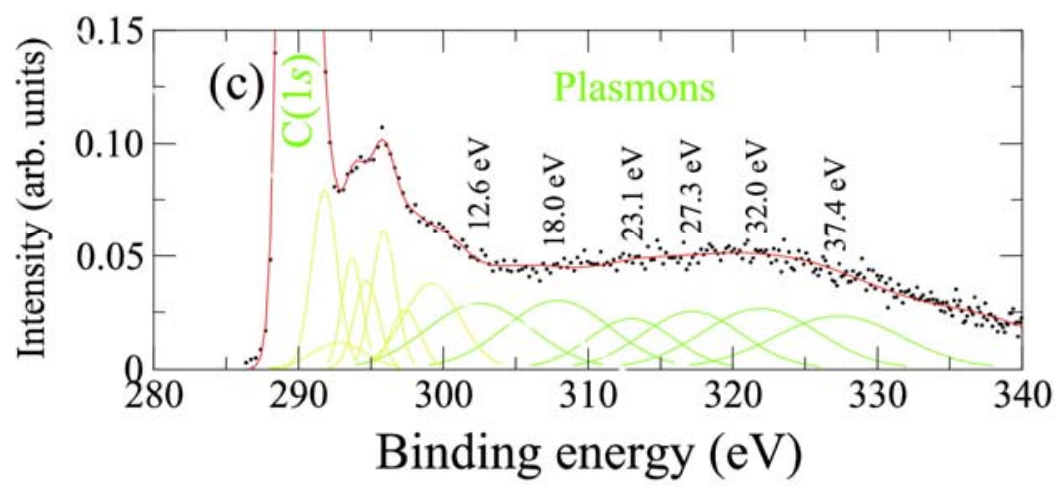

Figure 2 - A recorded spectrum of the $54.7^{\circ}$ - analyser for a photon energy of $390 \mathrm{eV}$ Puc. 2 - Анализатор спектра на $54.7^{\circ}$ дя энергии фотона $390 \mathrm{eV}$

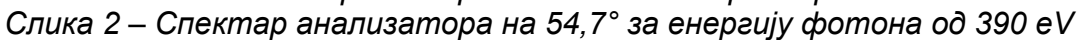

We have also studied the dynamical behaviour of plasmon excitation by recording the photoelectron spectra as a photon energy function. This is illustrated in Figure 3 for several different photon energies.

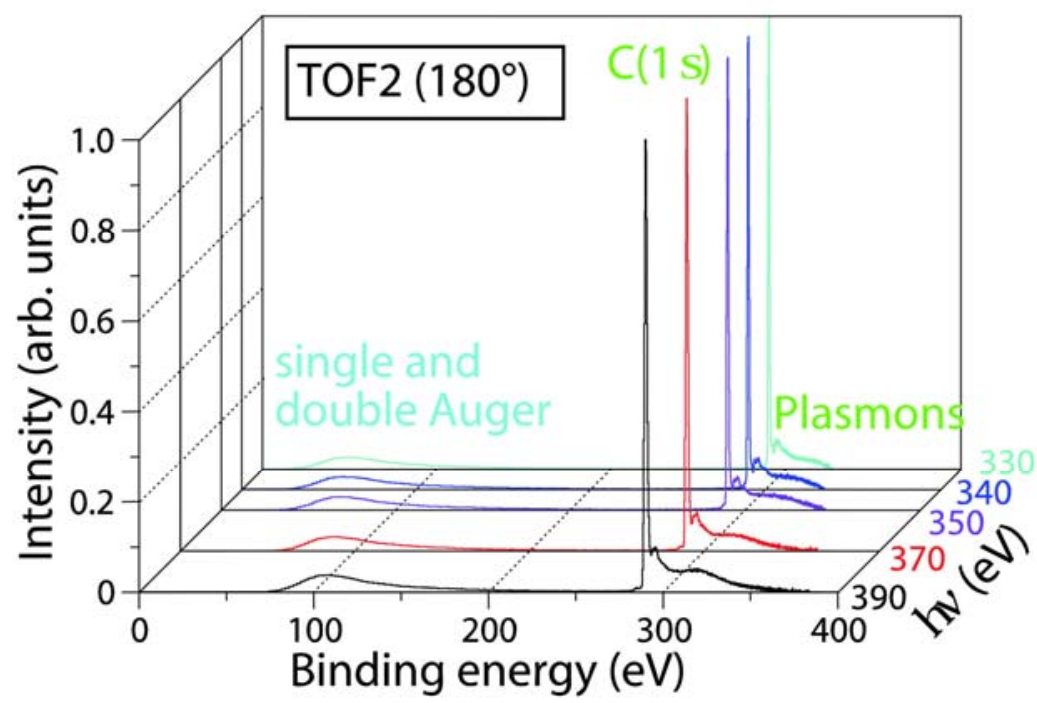

Figure 3 - Spectra as a function of the binding energy of the $180^{\circ}$-analyser for different photon energies

Puc. 3 - Спектр в функции связной энергии анализатора на $180^{\circ}$ для различных уровней энергии фотона

Слика 3 - Спектар у фрункцији од енергије везе за анализатор на $180^{\circ}$ за различите енергије фотона 
Our results are in good agreement with the model of T. D. Thomas (Thomas, 1984, pp.417-420), a time-dependent model which describes the transition between adiabatic and sudden behaviour. It takes into account the interaction between the outgoing electron and the remaining electrons which leads to shake-up satellite electrons because the photoejected electron may emerge with less energy than in the adiabatic picture. In addition, multiple electron ejection is possible, in which case a continuous shake-off spectrum is observed since the discrete energy can be arbitrarily divided between the emitted electrons. In the frame of this model, the intensity ratio of the "shake-up" process and the $\mathrm{C}(1 \mathrm{~s})$ line is given by the expression:

$$
\mu=\mu_{\infty} \exp \left\{-\left(r\left[\begin{array}{l}
0 \\
A
\end{array}\right] \Delta E[e V]\right)^{2} /\left(15.32 E_{e x}[e V]\right)\right\},
$$

where:

$\mu$ - intensity ratio of the "shake-up" process and the $\mathrm{C}(1 \mathrm{~s})$ main line,

$\mu_{\infty}$ - asymptotic value of $\mu$ (taken from Leiro et al, 2003, pp.205-213),

$r$ - the distance until the electrons are separated from the molecule,

$r \approx 0.4 A$, note: $r<<r\left(C_{60}\right)$,

$\Delta E$ - the excitation energy of the "shake-up" process,

$E_{e x}$ - the kinetic energy of the outgoing electrons.

Figure 4 shows a comparison of the experimental results with the results of the model of T. D. Thomas (Thomas, 1984, pp.417-420). With increasing energy, the plasmon intensity reaches its sudden limit faster than expected pointing to the localized excitation processes rather than to a delocalized relaxation in response to core-hole creation. The sudden limit intensity is as large as $30 \%$ of the total K-shell ionization events. Our measurements are in good agreement with the corresponding behavior of the satellite excitations in atoms such as $\mathrm{He}, \mathrm{Ne}$ and $\mathrm{Ar}$ (Holland et al, 1979, pp.2465-2484) where electron correlation effects are supposed to enhance various cross sections. 


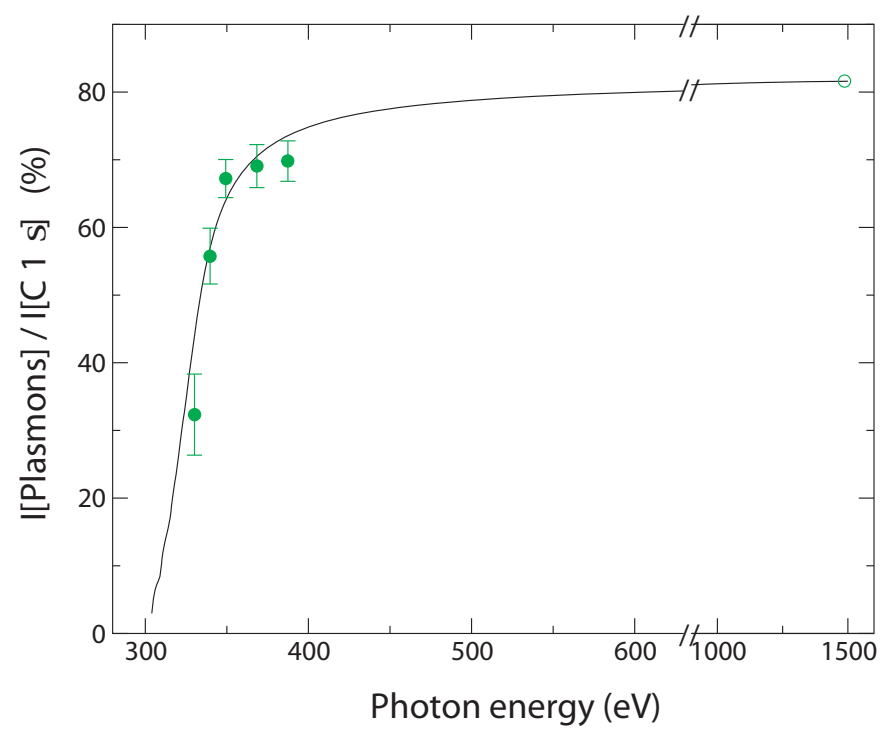

Figure 4 - Experimental and calculated values of the ratio of the intensity of all plasmon peaks and the intensity of the $C(1 s)$ main line as a function of excitation energy. Рис. 4 - Экспериментальные и расчетные значения отношений интенсивности всех плазмонных пиков и интенсивности C(1s) главной линии в фрункции энергии возбуждения.

Слика 4 - Експериментална и израчуната вредност односа интензитета свих пикова плазмона и интензитета C(1s) главне линије у функцији енергије ексцитације

\section{Double Auger decay of the excited C60}

The strength of the shake-off processes contributes also significantly to total K-shell ionization rate. The relative fraction of this shake-off rate has been, however, unknown so far, although the complete photoelectron spectra exhibit a large fraction of continuously distributed photoelectron intensity which could either result from shake-off photoelectron emission or double Auger decay (Fig.5). The quality of the former K-shell photoelectron measurements was insufficient to disentangle these two contributions experimentally (Aksela et al, 1995, pp.2112-2115), (LeBrun et al, 1994, pp.3965-3968), (Brühwiler et al, 1993, pp.3721-3724), (Krummacher et al, 1993, pp.8424-8429).

The contribution of different excitation events can by separated with the ansatz (Fig.5):

$$
\begin{aligned}
\text { Total Auger } & =\text { Auger }_{\text {single }}+\text { Auger }_{\text {double }} \\
& =C(1 s)+\text { Satellites }+ \text { Plasmons }+e_{\text {shakeoff }}
\end{aligned}
$$




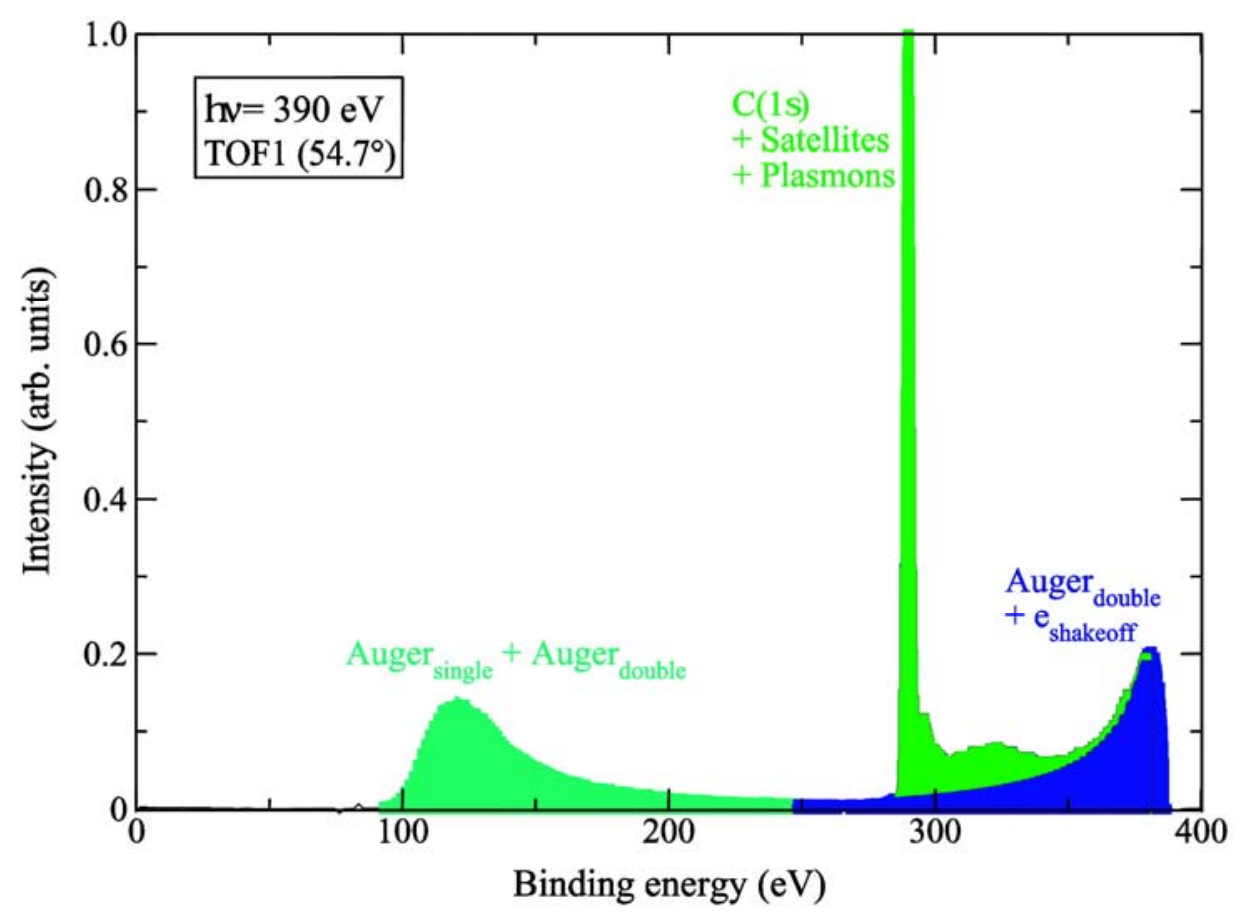

Figure 5 - Photoelectron spectrum recorded with a photon energy of $390 \mathrm{eV}$. Different types of contributions are marked with colours. The intensity of the single and double Auger process can be deduced from the coloured areas.

Puc. 5 - Фотоэлектронный спектр, записанный для энергии фотона 390eV.

Различные виды влияния обозначены разными цветами. Интенсивность Ожепроцессов можно определить по обозначенным частям.

Слика 5 - Фотоелектронски спектар снимлљен за енергију фотона 390eV. Различите врсте доприноса означене су различитим бојама. Интензитети Ожеових процеса могу се одредити из обојених области.

Performing a spectral analysis, which takes all primary and secondary ionization events into account, yields a double Auger rate as high as $60 \%$ of the total Auger yield. This is an extremely high value, raising the question of its origin. Assuming that the main line and the related shake-off emission result predominantly in single Auger decay, the K-shell photoionization associated with satellite and plasmon excitations remain the only plausible source for such a high double Auger rate.

The only reason for this highly unusual behaviour may be the fact that satellite and plasmon excitations both populate LUMO states which 
are strongly delocalized and may be completely in the continuum for the double charged $\mathrm{C}_{60}{ }^{2+}$ ion resulting from the $\mathrm{K}$-shell ionization and the subsequent core-hole refilling process (Maxwell et al, 1994, pp.1071710725), (Wästberg et al, 1994, pp.13031-13034). The excited electron cannot survive in this unstable situation and will consequently leave the $\mathrm{C}_{60}$ ion along with the Auger electron in a form of an Auger shake-off transition. These arguments, however, have to be validated by more sophisticated calculations.

\section{Conclusion}

We have studied the $\mathrm{C}_{60}$ molecule photoionization above the $\mathrm{C}(1 \mathrm{~s})$ threshold, in the photon energy range $h v=(330-390) e V$. A careful analysis of the spectra yielded two surprising and unexpected results:

(i) With energy increase, the plasmon intensity reaches its sudden limit faster than expected pointing to localized excitation processes rather than to a delocalized relaxation in response to core-hole creation. The sudden limit intensity is as large as $30 \%$ of the total K-shell ionization events.

(ii) Performing a spectral analysis taking all primary and secondary ionization events into account yields a double Auger rate as high as $60 \%$ of the total Auger yield.

The double Auger processes are probably linked to the plasmon excitation in the $\mathrm{C}_{60}$ molecules.

\section{References}

Aksela, S., Nõmmiste, E., Jauhiainen, J., Kukk, E., Karvonen, J., Berry, H.G., Sorensen S.L., Aksela, H. 1995. Photofragmentation of $\mathrm{C}_{60}$ Molecules following Resonance Excitation and ionization near the C1s Edge. Physical Review Letters, 75(11), pp.2112-2115. Available at: https://doi.org/10.1103/physrevlett.75.2112.

Amusia, M.Ya., \& Connerade, J.P. 2000. The theory of collective motion probed by light. Reports on Progress in Physics, 63(1), pp.41-70. Available at: https://doi.org/10.1088/0034-4885/63/1/202.

Benning, P.J., Poirier, D.M., Ohno, T.R., Chen, Y., Jost, M.B., Stepniak, F., Kroll, G.H., Weaver, J.H., Fure, J., \& Smalley, R.E. 1992. $C_{60}$ and $C_{70}$ fullerenes and potassium fullerides. Physical Review B, 45(12), pp.6899-6913. Available at: https://doi.org/10.1103/physrevb.45.6899. 
Bertsch, G.F., Bulgac, A., Tománek, D., \& Wang, Y. 1991. Collective Plasmon excitations in $\mathrm{C}_{60}$ clusters. Physical Review Letters, 67(19), pp.26902693. Available at: https://doi.org/10.1103/physrevlett.67.2690.

Brühwiler, P.A., Maxwell, A.J., Rudolf, P., Gutleben, C.D., Wästberg, B., \& Mårtensson, N. 1993. C1s autoionization study of electron hopping rates in solid $\mathrm{C}_{60}$. Physical Review Letters, 71(22), pp.3721-3724. Available at: https://doi.org/10.1103/physrevlett.71.3721.

Ekardt, W. 1984. Dynamical Polarizability of Small Metal Particles: SelfConsistent Spherical Jellium Background Model. Physical Review Letters, 52(21), pp.1925-1928. Available at: https://doi.org/10.1103/physrevlett.52.1925.

Electronic Properties of Fullerenes. Proceedings of the International Winterschool on Electronic Properties of Novel Materials. [e-book]. Edited by Kuzmany, H., Fink, J., Mehring, M., Roth, S. Tirol, March 6-13, 1993. Berlin: Springer Series in Solid-State Sciences, Vol.177. Available at: http://www.springer.com/gp/book/9783642850516. Accessed: 28 October 2017.

Hertel, I.V., Steger, H., de Vries, J., Weisser, B., Menzel, C., Kamke, B., \& Kamke, W. 1992. Giant plasmon excitation in free $\mathrm{C}_{60}$ and $\mathrm{C}_{70}$ molecules studied by photoionization. Physical Review Letters, 68(6), pp.784-787. Available at: https://doi.org/10.1103/physrevlett.68.784.

Holland, D.M.P., Codling, K., Marr, G.V., \& West, J.B. 1979. Multiple photoionisation in the rare gases from threshold to $280 \mathrm{eV}$. Journal of Physics $B$ : Atomic and Molecular Physics, 12(15), pp.2465-2484. Available at: https://doi.org/10.1088/0022-3700/12/15/008.

Karvonen, J., Nõmmiste, E., Aksela, H., \& Aksela, S. 1997. Photoion spectra of $\mathrm{C}_{60}$ molecules at resonance excitation and ionization energies near the C1s edge. The Journal of Chemical Physics, 106(9), pp.3466-3472. Available at: https://doi.org/10.1063/1.473442.

Korica, S., Rolles, D., Reinköster, A., Langer, B., Viefhaus, J., Cvejanović, S., \& Becker, U. 2005. Partial cross sections and angular distributions of resonant and non-resonant valence photoemission of $\mathrm{C}_{60}$. Physical Review $A$, 71(1), pp.132031-132035. Available at: https://doi.org/10.1103/physreva.71.013203.

Krätschmer, W., Lamb, L.D., Fostiropoulos, K., \& Huffman, D.R. 1990. Solid $\mathrm{C}_{60}$ : a new form of carbon. Nature, 347(6291), pp.354-358. Available at: https://doi.org/10.1038/347354a0.

Kroto, H.W., Heath, J.R., O'Brien, S.C., Curl, R.F., \& Smalley, R.E. 1985. $\mathrm{C}_{60}$ : Buckminsterfullerene. Nature, 318(6042), pp.162-163. Available at: https://doi.org/10.1038/318162a0.

Krummacher, S., Biermann, M., Neeb, M., Liebsch, A., \& Eberhardt, W. 1993. Close similarity of the electronic structure and electron correlation in gasphase and solid $\mathrm{C}_{60}$. Physical Review B, 48(11), pp.8424-8429. Available at: https://doi.org/10.1103/physrevb.48.8424. 
LeBrun, T., Berry, H.G., Cheng, S., Dunford, R.W., Esbensen, H., Gemmell, D.S., Kanter, E.P., \& Bauer, W. 1994. Ionization and Multifragmentation of $\mathrm{C}_{60}$ by High-Energy, Highly Charged Xe lons. Physical Review Letters, 72(25), pp.3965-3968. Available at: https://doi.org/10.1103/physrevlett.72.3965.

Leiro, J.A., Heinonen, M.H., Laiho, T., \& Batirev, I.G. 2003. Core-level XPS spectra of fullerene, highly oriented pyrolitic graphite, and glassy carbon. Journal of Electron Spectroscopy and Related Phenomena, 128(2-3), pp.205-213. Available at: https://doi.org/10.1016/s0368-2048(02)00284-0.

Lichtenberger, D.L., Nebesny, K.W., Ray, C.D., Huffman, D.R., \& Lamb, L.D. 1991. Valence and core photoelectron spectroscopy of $\mathrm{C}_{60}$, buckminsterfullerene. Chemical Physics Letters, 176(2), pp.203-208. Available at: https://doi.org/10.1016/0009-2614(91)90155-3.

Maxwell, A.J., Brühwiler, P.A., Nilsson, A., Mårtensson, N., \& Rudolf, P. 1994. Photoemission, autoionization, and $\mathrm{x}$-ray-absorption spectroscopy of ultrathin-film $\mathrm{C}_{60}$ on $\mathrm{Au}(110)$. Physical Review B, 49(15), pp.10717-10725. Available at: https://doi.org/10.1103/physrevb.49.10717.

Terminello, L.J., Shuh, D.K., Himpsel, F.J., Lapiano-Smith, D.A., Stöhr, J., Bethune, D.S., \& Meijer, G. 1991. Unfilled orbitals of $\mathrm{C}_{60}$ and $\mathrm{C}_{70}$ from carbon Kshell X-ray absorption fine structure. Chemical Physics Letters, 182(5), pp.491496. Available at: https://doi.org/10.1016/0009-2614(91)90113-n.

Thomas, T.D. 1984. Transition from Adiabatic to Sudden Excitation of Core Electrons. Physical Review Letters, 52(6), pp.417-420. Available at: https://doi.org/10.1103/physrevlett.52.417.

Wästberg, B., Lunell, S., Enkvist, C., Brühwiler, P.A., Maxwell, A.J., \& Mårtensson, N. 1994. 1s x-ray-absorption spectroscopy of $\mathrm{C}_{60}$ : The effects of screening and core-hole relaxation. Physical Review B, 50(17), pp.13031-13034. Available at: https://doi.org/10.1103/physrevb.50.13031.

Weaver, J.H., Martins, J.L., Komeda, T., Chen, Y., Ohno, T.R., Kroll, G.H., Troullier, N., Haufler, R.E., \& Smalley, R.E. 1991. Electronic structure of solid $\mathrm{C}_{60}$ : Experiment and theory. Physical Review Letters, 66(13), pp.1741-1744. Available at: https://doi.org/10.1103/physrevlett.66.1741.

УСИЛЕНИЕ ДВОЙНОГО ОЖЕ-РАСПАДА, СОПРОВОЖДАЮЩЕГО ВОЗБУЖДЕНИЕ ПЛАЗМОНОВ В С 60

Саня Л. Корица ${ }^{\mathrm{a}}$, Аксел Райнкостер ${ }^{6}$, Уве Бекер $^{\mathrm{B}}$

а Университет «Унион - Никола Тесла», Факультет экологии и охраны окружающей среды, г. Белград, Республика Сербия + Институт им. Фрица Габера, Отделение молекулярной физики, г. Берлин, Федеративная Республика Германия

${ }^{б}$ Институт им. Фрица Габера, Отделение молекулярной фризики, г. Берлин, Федеративная Республика Германия

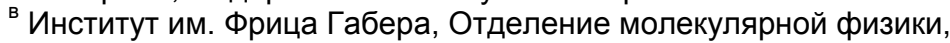
г. Берлин, Федеративная Республика Германия 
ОБЛАСТЬ: молекулярная физика, синхротронное излучение, Фотоэлектронная спектроскопия, фуллерены, дипольный резонанс, Оже-распад, плазмон, коллективные колебания, локализованное возбуждение, делокализованная релаксация

ВИД СТАТЬИ: оригинальная научная статья ЯЗЫК СТАТЬИ: английский

Резюме:

Одной из самых значительных свойств молекулы $C_{60}$ является коллективная реакция ее валентных электронов на электромагнитные излучения. Вследствие коллективной реакции в спектре поглащения возникает огромный дипольный резонанс (так называемый поверхностный плазмон), приблизительно на 20 eV, который был неоднократно представлен различными авторами в их теоретических исследованиях. В случае фотоэлектронной эмиссии, наблюдаются характерное поведение плазмонов при возбуждении на пороге ионизации. $B$ работе представлена новая серия фотоэлектронных спектров Коболочки, а также подробный квалитативный анализ всех ионизаций с возбуждениями в процессе двойной ионизации. На основании проведенного анализа и измерений плазмонного возбуждения $C_{60}$ при применении так называемого закона ТомасДерраха можно утверждать, что они полностью совпадают с соответствующим поведением сателлитного возбуждения атомов в неонах.

Ключевые слова: молекулярная фризика, фотоэлектронная спектроскопия, возбуждение плазмонов.

ЈАКО ПОЈАЧАҢЕ ДВОСТРУКОГ ОЖЕОВОГ РАСПАДА КОЈИ ПРАТИ ПЛАЗМОНСКУ ЕКСЦИТАЦИЈУ У $\mathrm{C}_{60}$

Сања љ. Корица ${ }^{a}$, Аксел Рајнкостер ${ }^{6}$, Уве Бекер $^{B}$

а Универзитет Унион - Никола Тесла, Факултет за екологију и заштиту животне средине, Београд, Република Србија + Институт Фриц Хабер, Одсек за молекуларну физику, Берлин, Савезна Република Немачка

${ }^{\sigma}$ Институт Фриц Хабер, Одсек за молекуларну физику, Берлин, Савезна Република Немачка

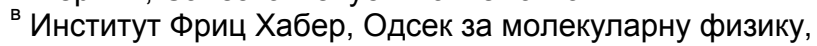
Берлин, Савезна Република Немачка

ОБЛАСТ: физика молекула, синхротронско зрачење, фотоелектронска спектроскопија, фулерени, диполна резонанца, Ожеов распад, Плазмон, колективна осцилација, локализована ексцитација, делокализована релаксација

ВРСТА ЧЛАНКА: оригинални научни чланак

ЈЕЗИК ЧЛАНКА: енглескИ 


\section{Сажетак:}

Једна од значајних карактеристика $C_{60}$ молекула је колективни одговор његових валентних електрона на електромагнетно зрачење. Ово колективно понашање доводи до појаве огромне диполне резонанце (тзв. површински плазмон) у апсорпционом спектру на око $20 \mathrm{eV}$, који су различити аутори и теоријски анализирали. Када је у питању фоотоелектронска емисија, плазмонску ексцитацију карактерише посебно понашање на прагу јонизације. Приказана је нова серија фотоелектронских спектара К-љуске са тежиштем на квалитативној анализи свих јонизација са ексцитацијама и процесима двоструке јонизације. Мерења плазмонске ексцитације $C_{60}$ прате тзв. Томас-Дирахов закон и у великој су сагласности са одговарајућим понашањем сателитских ексцитација у атомима као ито је неон.

Кључне речи: фризика молекула, фотоелектронска спектроскопија, плазмонска ексцитација.

Paper received on / Дата получения работы / Датум пријема чланка: 15.01.2018. Manuscript corrections submitted on / Дата получения исправленной версии работы / Датум достављања исправки рукописа: 07.04.2018.

Paper accepted for publishing on / Дата окончательного согласования работы / Датум коначног прихватања чланка за објављивање: 09.04.2018.

( 2018 The Authors. Published by Vojnotehnički glasnik / Military Technical Courier (www.vtg.mod.gov.rs, втг.мо.упр.срб). This article is an open access article distributed under the terms and conditions of the Creative Commons Attribution license (http://creativecommons.org/licenses/by/3.0/rs/).

() 2018 Авторы. Опубликовано в «Военно-технический вестник / Vojnotehnički glasnik / Military Technical Courier» (www.vtg.mod.gov.rs, втг.мо.упр.срб). Данная статья в открытом доступе и распространяется в соответствии с лицензией «Creative Commons» (http://creativecommons.org/licenses/by/3.0/rs/).

(c) 2018 Аутори. Објавио Војнотехнички гласник / Vojnotehnički glasnik / Military Technical Courier (www.vtg.mod.gov.rs, втг.мо.упр.срб). Ово је чланак отвореног приступа и дистрибуира се у складу са Creative Commons licencom (http://creativecommons.org/licenses/by/3.0/rs/).

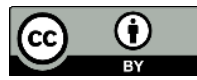

